Article

\title{
Community Based Programs Sustainability. A Multidimensional Analysis of Sustainability Factors
}

\author{
Sebastian Ion Ceptureanu ${ }^{1, *(\mathbb{D})}$, Eduard Gabriel Ceptureanu ${ }^{1}$ (1) , Cristian Eugen Luchian ${ }^{2}$ and \\ Iuliana Luchian $^{2}$ \\ 1 Department of Management, The Bucharest University of Economic Studies, 010374 Bucharest, Romania; \\ eduard.ceptureanu@man.ase.ro \\ 2 Department of Business Administration, The Bucharest University of Economic Studies, 010374 Bucharest, \\ Romania; eugen.luchian@ase.ro (C.E.L.); iulia.luchian@ase.ro (I.L.) \\ * Correspondence: sebastian.ceptureanu@man.ase.ro; Tel.: +40-740-019-879
}

Received: 17 February 2018; Accepted: 14 March 2018; Published: 19 March 2018

\begin{abstract}
Ensuring community based program sustainability is critical for the targeted communities. When such a program is no longer sustainable, its impact decreases, leading to unmet expectations, affecting the community as a whole. As such, scrutinizing sustainability factors for community based programs proves essential. This paper analyses those factors by reviewing the literature, questioning 188 individuals from community based organizations and other non-profits and providing a ranking for the most important of them. The factors were divided into 3 categories: related to program itself, related to host (implementing) organisation and related to the community where the program is operationalized. For data analysis several statistical tests were used, leading to a ranking of the most important 22 factors for community based programs sustainability.
\end{abstract}

Keywords: community based program sustainability; community based program; sustainability factors

\section{Introduction}

Community based programs (CBPs) may contribute to sustainable community development by using local resources and by improving transparency and equitably distribution the benefits of development while, on long term may improve living standards and quality of life in the involved communities. Community based programs are increasingly scrutinized in the literature literature [1-15] in the broader context of non-profit sector sustainability $[16,17]$. There are several reasons why program sustainability is important: (1) terminating an effective program leads to negative effects for both the community involved and for host organization; (2) program initiation costs are high; and (3) community experiencing unexpected program termination lose trust when future programs are to be introduced [18].

Simultaneously, community based programs sustainability it is a major concern for many non-profit organizations, and especially for community based organisations (CBOs) [19], with evidence from various studies indicating that around 40 per cent of all such programs terminates in their first few years of implementation, after the initial funding is discontinued [12], leaving community needs unmet.

To generate and achieve the expected impact upon targeted community, a community based program must sustain itself. Unfortunately, sustainability is seldom included in the program planning [20] while evaluation traditionally focuses on immediate outcomes, often neglecting long term sustainability [21], even though, to some extent, without their accomplishment it will not prove sustainable. Various frameworks and models are used by non-profits, aimed to create and support the process of sustainability [22]. Without focus on assessing the sustainability, the intended impact will be affected $[12,23,24]$. 


\section{Community Based Programs Sustainability and Sustainability Factors}

Community based programs are, according to literature, social interventions leading to social processes targeted to change the existent social structures and institutions simultaneously with altering social behavior of its members [25].

While sustainability is widely recognized in the literature, the concept itself is inconsistently defined [26], given the multiple dimension and stakeholders involved [7]. In a very broad way, sustainability is defined as "whether or not something continues to work over time" [27]. Other approaches are more detailed, with some scholars considering sustainability as addressing the program continuity in its entirety, while others addressed continuity of specific program components [26], improvement of community capacity, programs institutionalisation [19] or the capacity of the program to continuously respond to community issues [28]. These divergent definitions attest that definitional consensus has not been made, and congruent sustainability factors are considered by various scholars or practitioners.

In an extensive review on what constitutes CBP sustainability, some authors [18] suggested that indicators can be divided in three distinct types:

(1) individual-level, emphasizing benefits for individuals after the initial program funding terminates;

(2) organization-level, focusing on continuation of program activities within the host organization;

(3) community-level, focusing on the continued capacity of a community to develop and deliver programs.

Since community based programs sustainability cannot be approached unilaterally since they are not just traditional projects, it is important to understand their features differentiating them from traditional projects:

(1) Rely on a community-based approach. A community-based approach are ways of working in partnership with people of concern throughout community based program implementation [29]. These individuals are able to recognize community's capabilities or resources and use them effectively to provide solutions supporting the community's goals [29]. Various studies found out that this approach may be critical in CBP sustainability [30-33].

(2) Imply community acceptance and involvement. Commonly linked with the previous feature, community acceptance and involvement requires incorporation of the targeted community's needs in all aspects of CBPs [34]. Community acceptance rely on the support of CBP by stakeholders, improving as such program accountability [35] and contributing to better understanding of the stakeholders role [36]. Scholars argue that community members are able to better understand their problems and, as such, are better suited to use their skills and community resources to identify actual solutions to their needs [37], take into account local values [38] or contribute to an early detect of potential problems before they may escalate [39].

(3) Require socio-cultural acceptability. Community-based programs are encouraging social and cultural diversity [40] by acknowledging and considering community's beliefs, norms, and religion in program design and implementation [15]. As any CBP must use community cultural identity [41] to be sustainable, without proper consideration of socio-cultural acceptability, any CBP will undermine the community's socio-cultural orientation will be hindered by lack of trust or even rejection by community members, reducing its sustainability [15].

(4) Require management capabilities. Community based programs seek to achieve long term goals [42]. To achieve their sustainability, organizations involved (usually the community based organizations) need to possesses adequate management capabilities to ensure proper implementation. For instance, securing local resources [43] or ensuring task familiarity [44] are often cited in the literature. Good management require more than just technical skills and expertise required to successfully implement the program [45]. 
Unfortunately, a comprehensive overview of community based program sustainability factors does not exist $[28,46,47]$. Various studies investigate different factors, making it difficult to have a clear picture of what is important and what is not. Moreover, depending on the specific point of view one factor may be categorized differently.

In a balanced approach, Mijnarends et al. (2011) [8] discuss four sets of factors describing CBP sustainability:

(a) Human resources factor comprieses people involved in running the program, like their skills, for instance. This factor was highlighted in several other studies [19,48,49].

(b) Organisational setting factor, describing program coordination or management. This factor was analysed in other studies, like [18,19,48-51].

(c) Social and political environment factor includes elements from the program context. A complex factor, it was used in studies like $[19,23,50,51]$, comprising diverse items.

(d) Financial resources factor deals with financial resources required and/or available for the community based program $[18,50]$.

Others argue that CBP sustainability can be influenced by socio-political factors such as the existence of champions, political will or the capacity of stakeholders [22], leadership competence, effective collaboration or understanding the community [28]. Montemurro et al. [9], in a study analysing capacity-building, identify six critical factors (networking-partnering-information exchange-prioritizing- planning/implementing and supporting/sustaining) and eight contextual ones influencing capacity-building process (existing capacity-coordinator role-community connectionsnature of partnerships- funding- social context- geographic scale-time) [9].

Finally, other approaches focus on community environment, like community support for the program: [52-54], political legitimation [24] or socioeconomic context [55].

Hence, in our opinion most of the studies addressing community based programs sustainability factors can be divided in three categories: focused on program itself, focused on the host organization and its overall sustainability impact

\section{Conceptual Model}

Our model considers three types of sustainability factors for community based programs, related, as mentioned in the previous section, to program, organization and community. In this section we only present those factors confirmed as having an impact on community based programs.

(a) Program specific

(1) Coordinator competence $[7,9,28,56]$ describes the ability of community based program coordinator to set up realistic goals and develop plans for CBP program. Coordinator competence is particularly important in recognizing existing capacity and for engagement in the participatory process.

(2) Transparency $[12,57,58]$ describes the informing of community based program's stakeholders of the results of program processes and outcomes using recognized and suitable methods.

(3) Staff involvement and integration $[4,7,28,57,58]$ describes the inclusion of qualified staff in all stages of the community based program.

(4) Responsivity $[28,56,58]$ is the ability of the program to adapt to meet the continues changing of community needs.

(5) Program funding $[8,15,18,24,28,52,53,56,58-61]$ describes the availability of the financial resources for community-based project.

(6) Program theory $[12,53,55]$ describes the existence of a clear and coherent framework for the CBP in terms of, for example, target population, community needs or expected outcomes.

(7) Program effectiveness $[18,28,53,54,62]$ describes the capability of CBP to document its success and disseminate it among stakeholders. 
(8) Program flexibility [12,24,57] describes the ability of a community based program to adapt and evolve from the original pattern, according to changing circumstances.

(9) Program evaluation $[12,55,63]$ describes program capability to align its characteristics with the needs of its stakeholders. Program evaluation may be a prerequisite from program flexibility.

(10) Program champions $[18,24,28,53,57,60,64,65]$, one of the most common factor in CBO sustainability, describe individuals or organizations who promote the program in the community.

(11) Program integration with the host organization $[18,54,57,60,63,65]$ describes the degree of dependence of the program with the host organization.

(12) Understanding the community $[15,18,28,58,62,66]$ describes program ability to identify and integrate community needs and resources.

(13) Political legitimation $[23,24,46,62]$ describes program adaptation to the policies and regulations of the relevant stakeholders.

(b) Organizational specific

(1) Leadership $[1,28,56]$ describes host organization top management capacity to establish organizational goals congruent with the community based program, to integrate program development in overall organizational development and to be proactive in their achievement.

(2) Organizational system $[4,8,28,63,67,68]$ comprises a wide array of items, which in some studies are considered separate sustainability factors of their own, like financial management, securing income sources or human resources practices. In our study it describes host organization procedures and systems regarding HR and financing.

(3) Organizational stability $[1,60,63,69]$ describes host organization ability to integrate new elements and adapt its management systems and procedures accordingly.

(4) Partnering $[7,9,15]$ describes the host organization capacity to initiate and maintain relations with multiple partners. Partnering can be beneficial for multiple aspects, like funding or community acceptance, which in turn can make program more sustainable. Partnering can also be used to exchange information or know how transfer.

(5) Specific sustainability actions and processes $[63,67,68]$ describes organizational actions and processes designed to enhance its overall sustainability. Unlike Organizational system item, which focus on overall procedures and systems of organization, which incidentally may ensure sustainability, this variable describes actions established by host organization specifically targeting it, like developing fund-raising strategies or setting up and maintaining partnerships.

(c) Community specific

(1) Community participation [1,15] describes community awareness and involvement in community based program planning and implementation. The level of community participation determines whether the program becomes established, how quickly and successfully it consolidates, and how it responds and adapts to meet changing needs.

(2) Community context $[4,8,18,55]$ describes contextual factors affecting community. In the literature, it is a broad factor encompassing community problems, like relations with government, social inequalities, which usually vary from study to study and from community to community. In our study, it describes relations with governmental agencies.

(3) Community support [9] describes the community involvement in providing additional resources to the program, particularly financial contributions to increase the internal funding, reducing as such program dependency external resources and making it less vulnerable. 
(4) Community capacity $[6,7,9,15]$ describes community capability in terms of target group availability.

\section{Materials and Methods}

First stage or research design required a comprehensive review of literature related to community based sustainability. Among the issues encountered the most important was the different meaning attached to similar sustainability factors in various studies. This stage lead to 33 factors identified (Table 1), which were further reviewed, in the second stage, by 10 experts: 6 from non-profit sector (4 community based organizations and 2 non-government organizations, all previously implemented community based programs) and 4 from academia. Our initial identification of factor was fully backed up by experts, which accepted all 33 proposed factors for questionnaire phase of the research.

Table 1. Conceptual framework of variables.

\begin{tabular}{|c|c|c|c|}
\hline Variable & $\begin{array}{c}\text { Literature } \\
\text { Review }\end{array}$ & $\begin{array}{c}\text { Experts } \\
\text { Interview }\end{array}$ & Statistical Tests \\
\hline \multicolumn{4}{|c|}{ Program } \\
\hline Coordinator competence & Proposed & Accepted & Confirmed \\
\hline Transparency & Proposed & Accepted & Confirmed \\
\hline Staff involvement and integration & Proposed & Accepted & Confirmed \\
\hline Responsivity & Proposed & Accepted & Confirmed \\
\hline Program funding & Proposed & Accepted & Confirmed \\
\hline Program theory & Proposed & Accepted & Confirmed \\
\hline Program effectiveness & Proposed & Accepted & Confirmed \\
\hline Program flexibility & Proposed & Accepted & Confirmed \\
\hline Program evaluation & Proposed & Accepted & Confirmed \\
\hline Program champions & Proposed & Accepted & Confirmed \\
\hline Program integration with the host organization & Proposed & Accepted & Confirmed \\
\hline Understanding the community & Proposed & Accepted & Confirmed \\
\hline Political legitimation & Proposed & Accepted & Confirmed \\
\hline Demonstrating results & Proposed & Accepted & Rejected \\
\hline Managerial support and flexibility & Proposed & Accepted & Rejected \\
\hline Effective collaboration & Proposed & Accepted & Rejected \\
\hline \multicolumn{4}{|c|}{ Organizational } \\
\hline Leadership & Proposed & Accepted & Confirmed \\
\hline Organizational system & Proposed & Accepted & Confirmed \\
\hline Organizational stability & Proposed & Accepted & Confirmed \\
\hline Partnering & Proposed & Accepted & Confirmed \\
\hline Specific sustainability actions and processes & Proposed & Accepted & Confirmed \\
\hline Financial management and income sources & Proposed & Accepted & Rejected \\
\hline Human resources & Proposed & Accepted & Rejected \\
\hline Strategic planning & Proposed & Accepted & Rejected \\
\hline Existing capacity & Proposed & Accepted & Rejected \\
\hline \multicolumn{4}{|c|}{ Community } \\
\hline Community participation & Proposed & Accepted & Confirmed \\
\hline Community context & Proposed & Accepted & Confirmed \\
\hline Community support & Proposed & Accepted & Confirmed \\
\hline Community capacity & Proposed & Accepted & Confirmed \\
\hline Community leadership & Proposed & Accepted & Rejected \\
\hline Networking & Proposed & Accepted & Rejected \\
\hline Information exchange & Proposed & Accepted & Rejected \\
\hline Prioritizing & Proposed & Accepted & Rejected \\
\hline
\end{tabular}

To further test the validity of the research tools, 2 sub-samples were constructed: one from members of community based organizations (CBOs) and one from members of other types of organizations involved in CBPs, mainly NGOs. The rationale behind this action was that community based organizations are established specifically to implement community based programs, so they are genuinely and intrinsic involved in the program, while NGOs members may be temporarily or 
tangentially involved. For the respondents, the condition to be included in the sample was to have been involved in the past 5 years in at least one community based program, regardless if it was planning, implementation, and monitoring or evaluation stage. Out of 340 questionnaires sent by email, we received 188 complete ones (Table 2).

Table 2. Sample structure.

\begin{tabular}{cccc}
\hline Criteria & Description & $\mathbf{N}$ & $\%$ \\
\hline \multirow{2}{*}{ Respondent organization } & Community-based organisation (CBO) & 54 & $28.72 \%$ \\
& Non-government organisation (NGO) & 134 & $71.28 \%$ \\
\hline \multirow{2}{*}{ Respondent gender } & Male & 68 & $36.17 \%$ \\
& Female & 120 & $63.83 \%$ \\
\hline \multirow{2}{*}{ Respondent education } & ISCED 4 or less & 8 & $4.26 \%$ \\
& ISCED 5 and 6 & 102 & $54.26 \%$ \\
& ISCED 7 or more & 78 & $41.49 \%$ \\
\hline \multirow{2}{*}{ Respondent age } & Young (<30 years old) & 25 & $13.30 \%$ \\
& Middle aged (31-50 years old) & 154 & $81.91 \%$ \\
& Old (>50 years old) & 9 & $4.79 \%$ \\
\hline
\end{tabular}

The results of the two independent-sample (Table 3) showed no differences between the responses from. Hence, we proceed further without separating them.

Table 3. The results of the independent sample $t$-test.

\begin{tabular}{ccccc}
\hline CBO Sustainability Factors & Mann-Whitney U & Wilcoxon W & z & $\begin{array}{c}\text { Asymp. Sig. } \\
\text { (2-Tailed) }\end{array}$ \\
\hline & Program & & & \\
\hline Coordinator competence & 3631.5 & 5009.5 & -0.025 & 0.979 \\
Transparency & 3261.5 & $12,991.5$ & -0.661 & 0.508 \\
Effective collaboration & 3164.0 & $12,480.0$ & -0.943 & 0.345 \\
Staff involvement and integration & 3189.0 & $12,919.0$ & -1.090 & 0.275 \\
Responsivity & 3634.5 & $13,504.5$ & -0.016 & 0.986 \\
Program funding & 3077.0 & $12,668.0$ & -1.374 & 0.169 \\
Demonstrating results & 3535.0 & 4913.0 & -0.238 & 0.811 \\
Program theory & 3049.0 & $12,365.0$ & -1.312 & 0.189 \\
Program effectiveness & 3007.5 & $12,737.5$ & -1.250 & 0.211 \\
Understanding the community & 3432.5 & $13,162.5$ & -0.548 & 0.583 \\
Program flexibility & 3553.0 & $13,564.0$ & -0.338 & 0.735 \\
Political legitimation & 3337.0 & $12,928.0$ & -0.353 & 0.723 \\
Program evaluation & 3234.5 & $13,104.5$ & -1.236 & 0.216 \\
Program champions & 3081.0 & $11,992.0$ & -0.367 & 0.713 \\
Program integration with the host & 3315.0 & 4641.0 & -0.629 & 0.529 \\
organization & 3097.0 & 4322.0 & -0.969 & 0.332 \\
Managerial support and flexibility & Organizational & & & \\
\hline & 3480.0 & $13,071.0$ & -0.120 & 0.904 \\
Financial management and income sources & 2936.0 & $12,116.0$ & -1.194 & 0.232 \\
Organizational stability & 3216.5 & 4441.5 & -0.214 & 0.830 \\
Human resources & 3185.5 & $12,776.5$ & -0.618 & 0.535 \\
Existing capacity & 3373.0 & $12,826.0$ & -0.583 & 0.559 \\
Partnering & 3295.0 & $10,878.0$ & -0.160 & 0.872 \\
\hline Specific sustainability actions and processes & 3437.5 & $11,380.0$ & -0.343 & 0.731 \\
Leadership & & 4621.0 & -0.390 & 0.695 \\
Organizational system & $13,167.5$ & -0.535 & 0.592 \\
\hline
\end{tabular}


Table 3. Cont.

\begin{tabular}{ccccc}
\hline CBO Sustainability Factors & Mann-Whitney U & Wilcoxon W & z & $\begin{array}{c}\text { Asymp. Sig. } \\
\text { (2-Tailed) }\end{array}$ \\
\hline Community capacity & Community & & & \\
Prioritizing & 2808.0 & $11,719.0$ & -1.260 & 0.207 \\
Community context & 3293.5 & 4568.5 .0 & -0.258 & 0.795 \\
Community support & 2508.0 & $12,099.0$ & -2.752 & 0.005 \\
Community participation & 2888.0 & $11,144.0$ & -0.848 & 0.396 \\
Community leadership & 2770.0 & $11,681.0$ & -1.967 & 0.049 \\
Networking & 3112.0 & $12,023.0$ & -0.045 & 0.963 \\
Information exchange & 2576.0 & $12,029.0$ & -1.895 & 0.058 \\
\hline
\end{tabular}

The estimation of the reliability by Cronbach's coefficient (Table 4) revealed that all of them are acceptable and satisfactory [70].

Table 4. Reliability according to the Cronbach's coefficient $\alpha$.

\begin{tabular}{ccc}
\hline Construct & Number of Items & Cronbach \\
\hline Program specific & 16 & 0.841 \\
Organizational specific & 9 & 0.741 \\
Community specific & 8 & 0.902 \\
\hline
\end{tabular}

\section{Data Analysis and Results}

For each of the sustainability factors, the hypothesis were:

Hypothesis H0. The average score for sustainability factor importance in relation with the community based program is lower than 3.

Hypothesis H1. The average score for sustainability factor importance in relation with the community based program is higher than 3 .

The results of the $t$-tests for each item are depicted in Table 5 .

For Program specific sustainability factors, the t-tests rejected the null hypotheses for items Coordinator competence, Transparency, Staff involvement and integration, Responsivity, Program funding, Program theory, Program effectiveness, Program flexibility, Program evaluation, Program champions, Program integration with the host organization, Understanding the community and Political legitimation.

For Organizational specific sustainability factors, the t-tests rejected the null hypotheses for items Leadership, Organizational system, Organizational stability, Partnering and Specific sustainability actions and processes.

For Community specific sustainability factors, the t-tests rejected the null hypotheses for items Community participation, Community context, Community support and Community capacity.

Hence, these were further analyzed identify their ranking according to their impact on community based program continuity. 
Table 5. Extracted Sustainability factors for CBP.

\begin{tabular}{|c|c|c|c|c|c|c|c|c|}
\hline \multirow[t]{2}{*}{ Variable } & \multirow[t]{2}{*}{$\mathbf{t}$} & \multirow[t]{2}{*}{ df } & \multirow{2}{*}{$\begin{array}{c}\text { Sig. } \\
\text { (2-Tailed) }\end{array}$} & \multirow[t]{2}{*}{ Mean } & \multirow[t]{2}{*}{ SD } & \multirow{2}{*}{$\begin{array}{c}\text { Std. } \\
\text { Error } \\
\text { Mean }\end{array}$} & \multicolumn{2}{|c|}{$\begin{array}{l}95 \text { Percent Confidence } \\
\text { Interval of the Difference }\end{array}$} \\
\hline & & & & & & & Lower & Upper \\
\hline \multicolumn{9}{|c|}{ Program specific } \\
\hline $\begin{array}{l}\text { P_1. Coordinator } \\
\text { competence }\end{array}$ & 10.088 & 177 & 0.000 & 3.820 & 1.08 & 0.0813 & 0.659 & 0.980 \\
\hline P_2. Transparency & 8.673 & 181 & 0.001 & 3.650 & 1.02 & 0.075 & 0.505 & 0.802 \\
\hline $\begin{array}{l}\text { P_3. Staff involvement and } \\
\text { integration }\end{array}$ & 6.824 & 178 & 0.000 & 3.590 & 1.15 & 0.085 & 0.416 & 0.756 \\
\hline P_4. Responsivity & 6.073 & 183 & 0.002 & 3.540 & 1.21 & 0.087 & 0.366 & 0.720 \\
\hline P_5. Program funding & 5.438 & 186 & 0.000 & 3.470 & 1.17 & 0.085 & 0.296 & 0.634 \\
\hline P_6. Program theory & 5.057 & 169 & 0.003 & 3.420 & 1.09 & 0.083 & 0.258 & 0.588 \\
\hline P_7. Program effectiveness & 4.036 & 161 & 0.000 & 3.360 & 1.13 & 0.088 & 0.182 & 0.533 \\
\hline P_8. Program flexibility & 3.647 & 187 & 0.0003 & 3.340 & 1.28 & 0.093 & 0.156 & 0.524 \\
\hline P_9. Program evaluation & 3.980 & 177 & 0.0001 & 3.330 & 1.09 & 0.081 & 0.164 & 0.487 \\
\hline P_10. Program champions & 3.733 & 157 & 0.0002 & 3.320 & 1.07 & 0.084 & 0.149 & 0.483 \\
\hline $\begin{array}{l}\text { P_11. Program integration } \\
\text { with the host organization }\end{array}$ & 3.586 & 178 & 0.0004 & 3.310 & 1.17 & 0.087 & 0.140 & 0.485 \\
\hline $\begin{array}{l}\text { P_12. Understanding the } \\
\text { community }\end{array}$ & 2.879 & 172 & 0.0044 & 3.270 & 1.21 & 0.088 & 0.083 & 0.448 \\
\hline P_13. Political legitimation & 3.077 & 180 & 0.0024 & 3.240 & 1.06 & 0.078 & 0.087 & 0.398 \\
\hline \multicolumn{9}{|c|}{ Organizational specific } \\
\hline O_1. Leadership & 2.444 & 170 & 0.015 & 3.200 & 1.1 & 0.083 & 0.039 & 0.369 \\
\hline O_2. Organizational system & 6.770 & 184 & 0.000 & 3.605 & 1.220 & 0.089 & 0.429 & 0.782 \\
\hline $\begin{array}{l}\text { O_3. Organizational } \\
\text { stability }\end{array}$ & 6.759 & 175 & 0.000 & 3.563 & 1.100 & 0.083 & 0.398 & 0.727 \\
\hline O_4. Partnering & 6.335 & 176 & 0.000 & 3.503 & 1.050 & 0.079 & 0.346 & 0.659 \\
\hline $\begin{array}{l}\text { O_5. Specific sustainability } \\
\text { actions and processes }\end{array}$ & 3.907 & 171 & 0.000 & 3.343 & 1.150 & 0.088 & 0.170 & 0.516 \\
\hline \multicolumn{9}{|c|}{ Community specific } \\
\hline $\begin{array}{l}\text { C_1. Community } \\
\text { participation }\end{array}$ & 2.786 & 175 & 0.006 & 3.256 & 1.220 & 0.092 & 0.075 & 0.437 \\
\hline C_2. Community context & 2.658 & 182 & 0.009 & 3.230 & 1.170 & 0.086 & 0.059 & 0.400 \\
\hline C_3. Community support & 8.821 & 181 & 0.0001 & 3.752747 & 1.151203 & 0.085 & 0.584 & 0.921 \\
\hline C_4. Community capacity & 7.148 & 175 & 0.0002 & 3.642045 & 1.191515 & 0.089 & 0.464 & 0.819 \\
\hline
\end{tabular}

We further proceeded to rank the extracted factors (Table 6).

Table 6. Ranking of community based programs sustainability factors.

\begin{tabular}{|c|c|c|c|c|c|c|c|}
\hline Sustainability Factors & $\begin{array}{c}\text { Mann- } \\
\text { Whitney U }\end{array}$ & Wilcoxon W & $\mathbf{z}$ & $\begin{array}{l}\text { Asymp. Sig. } \\
\text { (2-Tailed) }\end{array}$ & Mean & $\begin{array}{l}\text { Category } \\
\text { Ranking }\end{array}$ & $\begin{array}{l}\text { Overall } \\
\text { Ranking }\end{array}$ \\
\hline P_10. Program champions & 3089.0 & $10,964.0$ & -0.746 & 0.456 & 3.906 & 1 & 1 \\
\hline $\begin{array}{l}\text { C_1. Community } \\
\text { participation }\end{array}$ & 2753.5 & $10,881.5$ & -2.506 & 0.012 & 3.893 & 1 & 2 \\
\hline $\begin{array}{l}\text { P_3. Staff involvement and } \\
\text { integration }\end{array}$ & 2729.5 & $10,479.5$ & -2.209 & 0.027 & 3.873 & 2 & 3 \\
\hline P_5. Program funding & 2891.0 & $10,517.0$ & -1.606 & 0.108 & 3.872 & 3 & 4 \\
\hline P_7. Program effectiveness & 3328.0 & $11,078.0$ & -0.840 & 0.401 & 3.862 & 4 & 5 \\
\hline P_1. Coordinator competence & 2856.5 & $11,241.5$ & -2.153 & 0.031 & 3.818 & 5 & 6 \\
\hline P_4. Responsivity & 3202.0 & $11,203.0$ & -1.040 & 0.298 & 3.786 & 6 & 7 \\
\hline C_4. Community capacity & 3000.0 & $10,381.0$ & -1.081 & 0.280 & 3.782 & 2 & 8 \\
\hline O_3. Organizational stability & 2949.0 & $10,699.0$ & -1.664 & 0.096 & 3.714 & 1 & 9 \\
\hline
\end{tabular}


Table 6. Cont.

\begin{tabular}{|c|c|c|c|c|c|c|c|}
\hline Sustainability Factors & $\begin{array}{c}\text { Mann- } \\
\text { Whitney U }\end{array}$ & Wilcoxon W & $\mathbf{z}$ & $\begin{array}{l}\text { Asymp. Sig. } \\
\text { (2-Tailed) }\end{array}$ & Mean & $\begin{array}{l}\text { Category } \\
\text { Ranking }\end{array}$ & $\begin{array}{l}\text { Overall } \\
\text { Ranking }\end{array}$ \\
\hline $\begin{array}{l}\text { P_12. Understanding the } \\
\text { community }\end{array}$ & 2922.5 & $11,568.5$ & -2.427 & 0.015 & 3.684 & 7 & 10 \\
\hline $\begin{array}{l}\text { P_11. Program integration } \\
\text { with the host organization }\end{array}$ & 3225.5 & $11,740.5$ & -1.454 & 0.146 & 3.667 & 8 & 11 \\
\hline P_8. Program flexibility & 2860.0 & $10,120.0$ & -1.466 & 0.143 & 3.655 & 9 & 12 \\
\hline $\begin{array}{l}\text { O_5. Specific sustainability } \\
\text { actions and processes }\end{array}$ & 2491.0 & 9994.0 & -1.573 & 0.116 & 3.646 & 2 & 13 \\
\hline C_3. Community support & 2466.0 & 9606.0 & -2.520 & 0.012 & 3.630 & 3 & 14 \\
\hline O_2. Organizational system & 2805.0 & $10,308.0$ & -1.795 & 0.073 & 3.600 & 3 & 15 \\
\hline P_6. Program theory & 2795.5 & $10,796.5$ & -1.771 & 0.077 & 3.566 & 10 & 16 \\
\hline O_1. Leadership & 3051.5 & $10,432,5$ & -1.103 & 0.270 & 3.536 & 4 & 17 \\
\hline P_13. Political legitimation & 2445.5 & 8886.5 & -1.218 & 0.223 & 3.531 & 11 & 18 \\
\hline O_4. Partnering & 2493.5 & 8379.5 & -0.808 & 0.419 & 3.440 & 5 & 19 \\
\hline P_2. Transparency & 2619.5 & 9879.5 & -1.539 & 0.124 & 3.412 & 12 & 20 \\
\hline C_2. Community context & 3043.0 & $11,299.0$ & -1.134 & 0.257 & 3.396 & 4 & 21 \\
\hline P_9. Program evaluation & 3305.5 & 4790.5 & -0.140 & 0.889 & 3.315 & 13 & 22 \\
\hline
\end{tabular}

\section{Discussion}

The list of the sustainability factors for community based programs includes: Program champions, Community participation, Staff involvement and integration, Program funding, Program effectiveness, Coordinator competence, Responsivity, Community capacity, Organizational stability, Understanding the community, Program integration with the host organization, Program flexibility, Specific sustainability actions and processes, Community support, Organizational system, Program theory, Leadership, Political legitimation, Partnering, Transparency, Community context and Program evaluation, in this order.

One finding is that sustainability of a community based program rely more on the quality of the program and less of the host organization or the community, with 9 out of 12 factors are related to the program, 2 to community and 1 to the host organization. In this respect, our study confirms previous studies, like Mancini et al. [24] or Shediac-Rizkallah and Bone [18] and to some extent Argaw et al. [1], Goodson et al. [60] or Savaya, et al. [64] and disagrees with the community focus advocated by studies such as Oino et al. [15].

According to each category of factors, we argue that:

(a) In terms of program related factors:

- Program champions (ranked 1 in its category and 1 overall) are described regularly as critical factors for various types of community based programs. Our study confirms this one more time. To enhance likelihood of CBP sustainability, its promoters must carefully seek and involve individuals or organizations trusted by the targeted community, facilitating further embeddedness of the program within existing community structures and key stakeholders.

- Staff involvement and integration (ranked 2 in its category and 3 overall) require inclusion of qualified staff in all stages of the community based program. The lack of adequately trained personnel is a major barrier while providing adequate staff training for effective program actions delivery supports CBP longevity. Integration is important since professionals involved may play a number of different roles in the program, requiring trust and good working relationships with both host organization and members of community.

- Program funding (ranked 3 in its category and 4 overall) implies funding needs assessment, development of a range of income sources, additional to funding agency payments and recognition that $\mathrm{CBP}$ sustainability is enhanced when there is diversity of support sources. 
Other actions must envisage efforts to obtain funding early in the program lifecycle or keeping CBP costs under control.

- Program effectiveness (ranked 4 in its category and 5 overall) is important in resources mobilization by careful documentation of its results and their dissemination among stakeholders. Advertisement of the CBP's effectiveness to stakeholders, to members of the community and to the general public serves may determine more community support.

- Coordinator competence (ranked 5 in its category and 6 overall) is particularly important in recognizing existing capacity and for engagement in the participatory process. A competent program leader brings consistency, avoiding mistakes like duplication of some early networking and partnering activity. Poor competence of the CBP leader affects all other sustainability factors, inefficient use of money and human resources, ineffectual promoting actions of the project and lack of trust from all program stakeholders.

- Responsivity (ranked 6 in its category and 7 overall) contribute to CBP sustainability by continuous adaptation of its activities or actions to the community needs or requirements. Even the best planning may face challenges on the ground due to the changes occurred in the targeted community.

- Understanding the community (ranked 7 in its category and 10 overall) lead to strong links with various individuals and organizations from the targeted community, making the program more likely to be sustainable. Creating a conducive environment for collaboration contributes to a CBP's continuation and that these ties determine community involvement by thoroughly implicating relevant community leaders and agencies.

- Program integration with the host organization (ranked 8 in its category and 11 overall) advocates for stronger ties between CBP processes within host organization processes since self-contained programs are less likely to be sustainable. So, the program must not be handles like a one-time project of the host organization but as a part of it, included in the development of organizational procedures.

- Program flexibility (ranked 9 in its category and 12 overall) is important in program sustainability since the ability to adapt to various circumstances may affect its chances for continuity.

- Program theory (ranked 10 in its category and 16 overall), part of program overall planning, impacts CBP sustainability by providing clear measurement metrics for key program features, like target population or community needs. Failure to correctly assess them may lead to unrealistic targets, waste of resources, and declining CBP desirability for both host organizations and funding agency.

- Political legitimation (ranked 11 in its category and 18 overall) provides congruence between program procedures and the policies and regulations of the relevant stakeholders. In our opinion, this sustainability factor is self-describing, so no further comments are necessary. Its ranking is not surprising, since careful compliance with government, public institutions or funding agencies regulations must be observed since the planning stage of the program.

- Transparency (ranked 12 in its category and 20 overall) influence CBP sustainability by making available for all those interested actual results, building trust in relation with program stakeholders and community members. Even the best CBPs in terms of outcomes delivered may terminate if are not able to disseminate, and program managing team lacks abilities to promote the program and build awareness.

- Program evaluation (ranked 13 in its category and 22 overall) is important in program overall sustainability since it can help in the development of strategies for sustainability.

(b) In terms of organization related factors:

- Organizational stability (ranked 1 in its category and 9 overall) is important in ensuring CBP sustainability. Host organization ability to integrate new elements and adapt its 
management systems and procedures accordingly was considered by the respondents as the most important organizational related factor. So, the flexibility of a community based program may be annulled by a rigid host organization, slowly upgrading its processes or systems to the program.

- Specific sustainability actions and processes (ranked 2 in its category and 13 overall) $[63,67,68]$ links program sustainability with what host organization build in terms of overall sustainability, such as developing a sustainability strategy or including an internal process dedicated to organizational sustainability. This provide the missing link to theories of non-profit sustainability and must be translated from organizational dedicated actions to program actions.

- Organizational system (ranked 3 in its category and 15 overall) relates to theories of capacity building and focus on two main organizational resources, financial and human resources. However, at organizational level the overall importance of these resources seems to decrease compared to program level, since program benefits from funding body/agency separate financing and employ specialists or experts outside host organization.

- Leadership (ranked 4 in its category and 17 overall) $[1,28,56]$, namely host organization top management capacity to establish goals for organization and to integrate program development in organizational development, seems less important. The probable reason is that program leader have a higher impact on its sustainability, while host organization management are tangentially involved, hence its importance.

- Partnering (ranked 5 in its category and 19 overall) $[7,9,15]$ comes as a surprise in terms of ranking. We expected a better position, since it describes the host organization capacity to get have relations with multiple partners. Being part of a network, for instance, may improve host organization capacity to makes the program more sustainable, like funding, easy access to experts or initial access to local community by partnership with a local NGO.

(c) In terms of program related factors:

- Community participation (ranked 1 in its category and 2 overall) determines how fast and successful the program consolidates. Not coincidentally in ranked 2nd in our study since community participation is an important factor for the CBP continuation as it is the genuine involvement of target community members as active participants are intrinsic to the program's sustainability.

- Community capacity (ranked 2 in its category and 8 overall) describes community capability in terms of target group actual availability. It is enabled by actions like target group information and may lead to results such as increased use of the facilities provided by the program by community members or attitude changes within the community. However, it can be difficult to know when a community reaches enough capacity to deal with program independently.

- Community support (ranked 3 in its category and 14 overall) must seek to integrate the program into community structures, making sense for the members of community to further support, especially financially the program once funding body terminate the funding. When local contribution does not exist, a community project will be too dependent on external resources and usually fails. Another consequence of unbalanced support sources is the risk of misusing power, since it is reasonable to believe that the party with the biggest investment has a more important role in decision making processes. In our opinion, a CBP must not start when it is clear from the beginning that the community is not willing to contribute to it.

- Community context (ranked 4 in its category and 21 overall) may lead to important sustainability risks, especially in communities with multiple and competing problems, making difficult for the program to achieve a critical mass in terms of partners, support or target group. 


\section{Conclusions}

This study aims to identify sustainability factors associated with community based program sustainability and rank them according to an estimated impact on program continuity, seen as the measure for CBPs sustainability. It reviewed the current literature and offered a comprehensive list of sustainability factors divided in three categories: program related, host organization related and community related, in our opinion the pillars of any community program. Also, it validated and ranked these factors.

Most of the literature has paid little attention to ranking sustainability factors for community based program, preferring to discuss specific program (health, disease prevention, education) factors for one or a limited number of CBPs. This study contributes to fill this gap by using $t$-test for identifying the most important factors which may, if carefully considered and addressed, influence sustainability, and ranking them based on their mean. The ranking determined the priority for community based programs coordinators and help them to come with adapted solutions for each of the aforementioned factors.

From the practical point of view, concentrating on the most important sustainability factors may provide a guide as to how program coordinators could deal with them, since we concluded that program related factors are more important than community or host organization related factors. Further studies may look more into community based programs specifics and particularly communities involved according to complex networks theories [71], with a focus on mapping the relations with various stakeholders [72] and on effectiveness and efficiency [73].

Author Contributions: All authors share equal contribution to this paper. All authors wrote the paper and revised the manuscript for intellectual content, read and approved the final manuscript.

Conflicts of Interest: The authors declare no conflict of interest.

\section{References}

1. Argaw, D.; Fanthahun, M.; Berhane, Y. Sustainability and factors affecting the success of community-based reproductive health programs in rural Northwest Ethiopia: Original research article. Afr. J. Reprod. Health 2007, 11, 79-88. [CrossRef] [PubMed]

2. Bennett, S.; Singh, S.; Ozawa, S.; Tran, N.; Kang, J.S. Sustainability of donor programs: Evaluating and informing the transition of a large HIV prevention program in India to local ownership. Glob. Health Action 2011, 4. [CrossRef] [PubMed]

3. Downey, L.H.; Castellanos, D.C.; Yadrick, K.; Threadgill, P.; Kennedy, B.; Strickland, E.; Bogle, M. Capacity Building for Health through Community-Based Participatory Nutrition Intervention Research in Rural Communities. Fam. Community Health 2010, 33, 175-185. [CrossRef] [PubMed]

4. Estabrooks, P.A.; Smith-Ray, R.L.; Dzewaltowski, D.A.; Dowdy, D.; Lattimore, D.; Rheaume, C.; Wilcox, S. Sustainability of evidence-based community-based physical activity programs for older adults: Lessons from Active for Life. Transl. Behav. Med. 2011, 1, 208-215. [CrossRef] [PubMed]

5. Gatchell, V.; Forsythe, V.; Thomas, P.R. The sustainability of community-based therapeutic care (CTC) in nonemergency contexts. Food Nutr. Bull. 2005, 27, 90-98. [CrossRef] [PubMed]

6. Hacker, K.; Tendulkar, S.A.; Rideout, C.; Bhuiya, N.; Trinh-Shevrin, C.; Savage, C.P.; DiGirolamo, A. Community capacity building and sustainability: Outcomes of community-based participatory research. Prog. Community Health Partnersh. 2012, 6, 349-360. [CrossRef] [PubMed]

7. Hanson, H.M.; Salmoni, A.W. Stakeholders' perceptions of programme sustainability: Findings from a community-based fall prevention programme. Public Health 2011, 125, 525-532. [CrossRef] [PubMed]

8. Mijnarends, D.; Pham, D.; Swaans, K.; Van Brakel, W.H.; Wright, P. Sustainability criteria for CBR programmes-two case studies of provincial programmes in Vietnam. Disabil. CBR Incl. Dev. 2011, 22, 3-21. [CrossRef]

9. Montemurro, G.R.; Raine, K.D.; Nykiforuk, C.I.; Mayan, M. Exploring the process of capacity-building among community-based health promotion workers in Alberta, Canada. Health Promot. Int. 2014, 29, 463-473. [CrossRef] [PubMed] 
10. Paine-Andrews, A.; Fisher, J.L.; Campuzano, M.K.; Fawcett, S.B.; Berkley-Patton, J. Promoting sustainability of community health initiatives: An empirical case study. Health Promot. Pract. 2000, 1, 248-258. [CrossRef]

11. Romani, M.E.T.; Vanlerberghe, V.; Perez, D.; Lefevre, P.; Ceballos, E.; Bandera, D.; Van der Stuyft, P. Achieving sustainability of community-based dengue control in Santiago de Cuba. Soc. Sci. Med. 2007, 64, 976-988. [CrossRef] [PubMed]

12. Savaya, R.; Spiro, S.; Elran-Barak, R. Sustainability of social programs a comparative case study analysis. Am. J. Eval. 2008, 29, 478-493. [CrossRef]

13. Tomioka, M.; Braun, K.L. Examining sustainability factors for organizations that adopted Stanford's chronic disease self-management program. Front. Public Health 2014, 2, 158-165. [CrossRef] [PubMed]

14. Walsh, A.; Mulambia, C.; Brugha, R.; Hanefeld, J. The problem is ours, it is not CRAIDS'. Evaluating sustainability of Community Based Organisations for HIV/AIDS in a rural district in Zambia. Glob. Health 2012, 8, 40. [CrossRef] [PubMed]

15. Oino, P.G.; Towett, G.; Kirui, K.K.; Luvega, C. The Dilemma in Sustainability of Community-Based Projects in Kenya. Glob. J. Adv. Res. 2015, 2, 757-768.

16. Ceptureanu, S.I.; Ceptureanu, E.G.; Orzan, M.C.; Marin, I. Toward a Romanian NPOs Sustainability Model: Determinants of Sustainability. Sustainability 2017, 9, 966. [CrossRef]

17. Ceptureanu, S.I.; Ceptureanu, E.G.; Bogdan, V.L.; Radulescu, V. Sustainability Perceptions in Romanian Non-Profit Organizations: An Exploratory Study Using Success Factor Analysis. Sustainability 2018, 10, 294. [CrossRef]

18. Shediac-Rizkallah, M.C.; Bone, L.R. Planning for the sustainability of community-based health programs: Conceptual frameworks and future directions for research, practice and policy. Health Educ. Res. 1998, 13, 87-108. [CrossRef] [PubMed]

19. Gruen, R.L.; Elliott, J.H.; Nolan, M.L.; Lawton, P.D.; Parkhill, A.; McLaren, C.J.; Lavis, J.N. Sustainability science: An integrated approach for health-programme planning. Lancet 2008, 372, 1579-1589. [CrossRef]

20. Sridharan, S.; Go, S.; Zinzow, H.; Gray, A.; Barrett, M.G. Analysis of strategic plans to assess planning for sustainability of comprehensive community initiatives. Eval. Program Plan. 2007, 30, 105-113. [CrossRef] [PubMed]

21. Cassidy, E.F.; Leviton, L.C.; Hunter, D.E.K. The relationship of program and organizational capacity to program sustainability. Eval. Program Plan. 2006, 29, 149-152. [CrossRef]

22. Glasgow, R.E.; Vogt, T.M.; Boles, S.M. Evaluating the public health impact of health promotion interventions: The RE-AIM framework. Am. J. Public Health 1999, 89, 1322-1327. [CrossRef] [PubMed]

23. Sarriot, E.G.; Winch, P.J.; Ryan, L.J.; Edison, J.; Bowie, J.; Swedberg, E.; Welch, R. Qualitative research to make practical sense of sustainability in primary health care projects implemented by non-governmental organizations. Int. J. Health Plan. Manag. 2004, 19, 3-22. [CrossRef] [PubMed]

24. Scheirer, M.A. Is sustainability possible? Am. J. Eval. 2005, 26, 320-347. [CrossRef]

25. Meyer, W. Sociological Theory and Evaluation Research, an Application and Its Usability for Evaluating Sustainable Development; Centrum fur Evaluation: Saarbrucken, Germany, 2002.

26. DeMiglio, L.; Williams, A.M. A qualitative study examining the sustainability of shared care in the delivery of palliative care services in the community. BMC Palliat. Care 2013, 12, 32. [CrossRef] [PubMed]

27. Abrams, L.; Palmer, I.; Hart, T. Sustainability Management Guidelines; Department of Water Affairs and Forestry: Pretoria, South Africa, 1998.

28. Mancini, J.A.; Marek, L.I. Sustaining community-based programs for families. Fam. Relat. 2004, 53, $339-347$. [CrossRef]

29. Office of the United Nations High Commissioner for Refugees (UNHCR). A Community-Based Approach in UNHCR Operations; UNHCR: Geneva, Switzerland, 2008.

30. Katz, T.; Sara, J. Making rural water supply sustainable: Recommendations from a global study. Working Paper, UNDP World Bank Water and Sanitation Program. 1997. Available online: http://documents. worldbank.org/curated/en/358261468200668527/pdf/multi-page.pdf (accessed on 14 March 2018).

31. Newman, P.; Kenworthy, J. Sustainability and Cities: Overcoming Automobile Dependence; Island Press: Washington, DC, USA, 1999.

32. Cleaver, F. Paradoxes of participation: Questioning participatory approaches to development. J. Int. Dev. 1999, 11, 597-612. [CrossRef] 
33. Narayan, D. The Contribution of People's Participation: Evidence from 121 Rural Water Supply Projects; Environmentally Sustainable Development Occasional Papers No. 1; World Bank: Washington, DC, USA, $1995 ; 116 p$.

34. Racino, J. People want the same things we all do: The story of the Area Agency in Dover, New Hampshire. In Policy, Programme Evaluation and Research in Disability: Community Support for All; Racino, J.A., Ed.; The Hayworth Press: Binghamton, NY, USA, 1999; pp. 119-137.

35. Cornwall, A.; Lucas, H.; Pasteur, K. Introduction: Accountability through participation: Developing workable partnership models in the health sector. IDS Bull. 2000, 31, 1-13. [CrossRef]

36. Mulwa, F. Demystifying Participatory Community Development, Revised ed.; Pauline's Publications Africa: Nairobi, Kenya, 2010.

37. Karl, M. Monitoring and Evaluating Stakeholder Participation in Agriculture and Rural Development Projects: A Literature Review; SD Dimensions; FAO: Rome, Italy, 2000.

38. Oakley, P.; Pratt, B.; Clayton, A. Outcomes and Impact: Evaluating Change in Social Development; INTRAC NGO Management and Policy Series No. 6; INTRAC: Oxford, UK, 1998.

39. Rudqvist, A.; Woodford-Berger, P. Evaluation and Participation: Some Lessons; SIDA Studies in Evaluation 96/1; SIDA: Stockholm, Sweden, 1996.

40. Roseland, M.; Connelly, S.; Hendrickson, D.; Lindberg, C.; Lithgow, M. Towards Sustainable Communities: Resources for Citizens and Their Governments, Revised ed.; New Society Publishers: Gabriola Island, BC, Canada, 2005.

41. Matthews, J.; Herbert, D. (Eds.) Unifying Geography: Common Heritage, Shared Future? Routledge: Oxfordshire, UK, 2004.

42. Wanjohi, A.M. Sustainability of Community Based Projects in Developing Countries: A Study of Sustainability Issues Facing Community Based Projects in Rural Areas of Mbeere District in Kenya; LAP Lambert Academic Publishing: Saarbrücken, Germany, 2010.

43. Rees, G.; Huby, G.; McDade, L.; McKechnie, L. Joint working in community mental health teams: Implementation of an integrated care pathway. Health Soc. Care Community 2004, 12, 527-536. [CrossRef] [PubMed]

44. Espinosa, J.A.; Slaughter, S.A.; Kraut, R.E.; Herbsleb, J.D. Familiarity, Complexity, and Team Performance in Geographically Distributed Software Development. Org. Sci. 2007, 18, 613-630. [CrossRef]

45. Hecht, S.; Kandel, S.; Gomes, I.; Cuellar, N.; Rosa, H. Globalization, Forest Resurgence, and Environmental Politics in El Salvador. World Dev. 2006, 34, 308-323. [CrossRef]

46. Pluye, P.; Potvin, L.; Denis, J. Making public health programs last: Conceptualizing sustainability. Eval. Program Plan. 2004, 27, 121-133. [CrossRef]

47. Sharir, M.; Lerner, M. Gauging the success of social ventures initiated by individual social entrepreneurs. J. World Bus. 2006, 41, 6-20. [CrossRef]

48. LaFond, A.K.; Brown, L.; Macintyre, K. Mapping capacity in the health sector: A conceptual framework. Int. J. Health Plan. Manag. 2002, 17, 3-22. [CrossRef] [PubMed]

49. Nu'Man, J.; King, W.; Bhalakia, A.; Criss, S. A framework for building organizational capacity integrating planning, monitoring, and evaluation. J. Public Health Manag. Pract. 2007, 13, S24-S32. [CrossRef]

50. Jacobs, B.; Price, N.; Sam, S.O. A sustainability assessment of a health equity fund initiative in Cambodia. Int. J. Health Plan. Manag. 2007, 22, 183-203. [CrossRef] [PubMed]

51. Sarriot, E.G.; Winch, P.J.; Ryan, J.; Bowie, J.; Kouletio, M.; Swedberg, E.; LeBan, K.; Edison, J.; Welch, R.; Pacqué, C. A methodological approach and framework for sustainability assessment in NGO-implemented primary health care programs. Int. J. Health Plan. Manag. 2004, 19, 23-41. [CrossRef] [PubMed]

52. Light, P.C. Sustaining Innovation: Creating Nonprofit and Government Organizations that Innovate Naturally; Jossey-Bass: San Francisco, CA, USA, 1998.

53. Steadman, H.J.; Cocozza, J.J.; Dennis, D.L.; Lassiter, M.G.; Randolph, F.L.; Goldman, H.; Blasinsky, M. Successful program maintenance when federal demonstration dollars stop: The access program for homeless mentally ill persons. Adm. Policy Ment. Health 2002, 29, 481-493. [CrossRef] [PubMed]

54. Padgett, S.M.; Bekemeier, B.; Berkowitz, B. Building sustainable public health systems change at the state level. J. Public Health Manag. Pract. 2005, 11, 109-115. [CrossRef] [PubMed] 
55. Weiss, H.; Coffman, J.; Bohan-Baker, M. Evaluation's role in supporting initiative sustainability. In Proceedings of the Fifth Bi-Annual Meeting of the Urban Seminar Series on Children's Health and Safety at Harvard University, Cambridge, MA, USA, 5-6 December 2002.

56. Akerlund, K.M. Prevention program sustainability: The state's perspective. J. Community Psychol. 2000, 28, 353-362. [CrossRef]

57. O'Loughlin, J.; Renaud, L.; Richard, L.; Gomez, L.S.; Paradis, G. Correlates of the sustainability of community-based heart health promotion intervention. Prev. Med. 1998, 27, 702-712. [CrossRef] [PubMed]

58. Holder, H.D.; Moore, R.S. Institutionalization of community action projects to reduce alcohol use and related problems: Systematic facilitators. Subst. Use Misuse 2000, 35, 75-86. [CrossRef] [PubMed]

59. Marek, L.I.; Mancini, J.A.; Brock, D.J. Continuity, Success, and Survival of Community-Based Projects: The National Youth at Risk Program Sustainability Study. 1999. Available online: http:/ / www.ext.vt.edu/pubs / family/350-801/350-801.html (accessed on 17 December 2017).

60. Goodson, P.; Smith, M.M.; Evans, A.; Meyer, B.; Gottlieb, N.H. Maintaining prevention in practice: Survival of PPIP in primary care settings. Am. J. Prev. Med. 2001, 20, 184-189. [CrossRef]

61. Stevens, B.; Peikes, D. When the funding stops: Do grantees of the Local Initiative Fund Partners Program sustain themselves? Eval. Program Plan. 2006, 29, 153-161. [CrossRef]

62. Pentz, M.A. Institutionalizing community-based prevention through policy change. J. Community Psychol. 2000, 28, 257-270. [CrossRef]

63. Johnson, K.; Hays, C.; Center, H.; Daley, C. Building capacity and sustainable prevention innovations: A sustainability planning model. Eval. Program Plan. 2004, 27, 135-149. [CrossRef]

64. Savaya, R.; Elsworth, G.; Rogers, P. Projected sustainability of innovative social programs. Eval. Rev. 2008, 33, 189-205. [CrossRef] [PubMed]

65. Smith, M.; Buckwalter, K.C.; Zevenbergen, P.W.; Kudart, P.; Springer-Brenneman, D.; Garand, L. An administrator's dilemma: Keeping the innovative mental health and aging programs alive after the grant funds end. J. Ment. Health Adm. 1993, 20, 212-222. [CrossRef] [PubMed]

66. Mancini, J.A.; Martin, J.A.; Bowen, G.L. Community capacity. In Encyclopedia of Primary Prevention and Health Promotion; Gullotta, T.P., Bloom, M., Eds.; KJuwer Academic/Plenum: New York, NY, USA, 2003; pp. 319-330.

67. Beery, W.L.; Senter, S.; Cheadle, A.; Greenwald, H.P.; Pearson, D.; Brousseau, R.; Nelson, G. Evaluation of the legacy of community health initiatives. Am. J. Eval. 2005, 26, 150-165. [CrossRef]

68. Robinson, K.; Elliot, S.J.; Driedger, M.; Eyles, J.; O’Loughlin, J.; Riley, B.; Cameron, R.; Harvey, D.; CHHDP Strategic and Research Advisory Groups. Using linking systems to build capacity and enhance dissemination in heart health promotion: A Canadian multiple-case study. Health Educ. Res. 2005, 20, 499-513. [CrossRef] [PubMed]

69. Pluye, P.; Potvin, L.; Denis, J.; Pelletier, J.; Mannoni, C. Program sustainability begins with the first events. Eval. Program Plan. 2005, 28, 123-137. [CrossRef]

70. Streiner, D.L. Diagnosing tests: Using and misusing diagnostic and screening tests. J. Personal. Assess. 2003, 81, 209-219. [CrossRef] [PubMed]

71. Cinelli, M.; Ferraro, G.; Iovanella, A. Rich-club ordering and the dyadic effect: Two interrelated phenomena. Phys. A 2018, 490, 808-818. [CrossRef]

72. Ferraro, G.; Iovanella, A. Organizing collaboration in inter-organizational innovation networks, from orchestration to choreography. Int. J. Eng. Bus. Manag. 2015, 7, 24. [CrossRef]

73. Mihaiu, D.M.; Opreana, A.; Cristescu, M.P. Efficiency, effectiveness and performance of the public sector. Romanian J. Econ. Forecast. 2010, 13, 132-147.

(C) 2018 by the authors. Licensee MDPI, Basel, Switzerland. This article is an open access article distributed under the terms and conditions of the Creative Commons Attribution (CC BY) license (http://creativecommons.org/licenses/by/4.0/). 